\title{
JEZZYK POLSKIEJ AGORY WIRTUALNEJ - ŻARGON CZY PIDGIN? PRÓBA DEFINICJI NA PODSTAWIE OPRACOWANIA McARTHURA (1992)
}

\author{
DANUTA OCHOTNA
}

\section{Wstęp}

Wiele się słyszy o języku używanym w Internecie. Jednak niewiele osób zdaje sobie sprawę, iż język służący do komunikacji w cyberprzestrzeni to tylko część, jaką stanowi język używany na agorze wirtualnej. Poprzez język używany na agorze wirtualnej należy rozumieć także język stosowany w SMS-ach, podczas rozmów telefonicznych, czy też podczas rozmów audio-wizualnych dokonywanych przy pomocy medium, jakim jest Internet. Konieczne jest, zatem, aby pamiętać o wszystkich elementach znajdujących się pod nazwą ,język stosowany na agorze wirtualnej”.

Celem tego artykułu jest określenie statusu języka stosowanego na agorze wirtualnej. Wielu badaczy tematu jest świadomych, że język ten jest dość specyficzny i w głównej mierze rozumiany tylko przez użytkowników tej formy komunikacji. Jednak niewielu z tych użytkowników umiałby określić rodzaj języka, którym się posługują w przestrzeni wirtualnej. Chciałabym wyróżnić trzy formy, które wezmę pod uwagę przy określaniu statusu języka. Są to: gwara, żargon, lingua franca, do której należą pidgin oraz creole. Określenie statusu języka stosowanego na agorze wirtualnej oprę zarówno na definicjach podanych wcześniej etapów języka oraz na przeprowadzonych przeze mnie badaniach. Jak można dostrzec użyłam terminu „etapy języka”, ponieważ, aby dana odmiana została uznana za język musi przejść swojego rodzaju zmiany następującej najczęściej w wyniku kontaktu z innym językiem naturalnym. 


\subsection{Przedstawienie definicji}

Zaczynając od definicji, zadajmy sobie pytanie, czym w ogóle jest żargon? Według internetowego Stownika Jezzyka Polskiego PWN, żargon jest to „środowiskowa odmiana języka" (ŻI 1). Jednakże do takiej definicji można dopasować wiele przykładów żargonu szukając głównie wśród form stosowanych w poszczególnych grupach zawodowych. Dlatego uważam, że należy doprecyzować definicję żargonu. Papierowe wydanie tego samego słownika definiuje żargon, jako: „odmiana języka ogólnonarodowego, różniąca się od niego swoistym słownictwem” (zob. Sobol, 1999: 1175). Inny internetowy słownik języka polskiego podaje również, iż żargon różni się od ogólnie przyjętego języka nie tylko słownictwem, ale także wyrażeniami i wymową (ŹI 2).

Kolejną definicję, jaką należy przedstawić jest definicja gwary. Za gwarę uważa się „mowę ludności zamieszkującej pewien obszar kraju, różniąca się pewnymi cechami od języka ogólnonarodowego" (zob. Sobol, 1999: 243). Słownik internetowy doprecyzowuje cechy odróżniające gwarę od języka ogólnonarodowego i są to: „zasób słów, wyrażeń, wymowa” (ŹI 3). Jak można zauważyć, zarówno w przypadku żargonu, jak i gwary cechami odróżniającymi je od ogólnonarodowej mowy jest zasób słownictwa oraz wymowa, jaka jest stosowana przez środowiska używające żargonu, czy gwary. Co więcej, wszystkie źródła, z których zaczerpnięte są definicje, wskazują, że można stosować zamiennie słowa żargon i gwara. Czy jest zatem jakaś różnica między tymi określeniami? Jeśli tak, to na czym ona polega? Otóż gwara, jak pisze McArthur (1992), jest to termin oznaczony w języku angielskim jako dialect $\mathrm{i}$ odnosi się do niego jako odmiany języka używanej w danym regionie, ale także słowo dialect może odnosić się do języka stosowanego przez osoby z danej klasy społecznej, czy z danego środowiska zawodowego (zob. McArthur, 1992: 289290). Z kolei żargon odnosi się do konkretnej grupy zawodowej, której zasób słownictwa i terminy (np. medyczne, czy prawnicze) dla osób niezwiązanych z daną grupą są niezrozumiałe (zob. McArthur, 1992: 543). Co prawda definicje McArthura odnoszą się do żargonu i gwary związanych z językiem angielskim, ale przytaczam te definicje, ponieważ uważam, iż idealnie oddają różnicę między gwarą i żargonem także w języku polskim.

Język, jak powszechnie wiadomo, jest tworem żywym i nieustannie podlega zmianom. Zmiany te mogą występować w obrębie dźwięków, leksyki czy gramatyki (zob. McArthur, 1992: 576-577). Zmiany językowe zachodzą w określonej przestrzeni komunikacyjnej oraz na 'przestrzeni' czasu (zob. McArthur, 1992: 576). Ponadto zmiany te mogą występować stopniowo lub gwałtownie (w szczególności podczas pidginizacji języka) (zob. McArthur, 1992: 576). Zmiany w obrębie dźwięków (fonologiczne) dotyczą sposobów wymawiania danych głosek (zob. McArthur, 1992: 576). Jedną ze zmian w języku polskim jest zmiana / 1 /, czy tzw. 'ciemnego /1/,' charakterystycznego na terenach wschodnich obecnej Polski i byłych Kresach, na ówczesne A/. 
Kolejnymi etapami zmian językowych następującymi po sobie są pidgin oraz creole. Zarówno creole, jak i pidgin należą do grupy, którą określa się jako lingua franca. McArthur (1992) zdefiniował lingua franca na dwa sposoby: (1) po pierwsze, jest to język przyjęty (J) przez daną grupę (G1) i używany przez nią w celach komunikacyjnych z inną grupą (G2) (zob. McArthur, 1992: 606). Należy wtedy zakładać, iż J jest językiem obcym dla G1 oraz językiem rodzimym dla G2. (2) Po drugie, lingua franca oznacza połączenie dwóch języków używane w celach komunikacyjnych i nazywane pidgin lub creole w zależności od stopnia rozwoju (zob. McArthur, 1992: 606). Przykładem pierwszego znaczenia określenia lingua franca jest język angielski, który od końca XX wieku aż po czasy obecne pełni rolę środka komunikacji na całym świecie (zob. McArthur, 1992: 606).

Creole pierwotnie odnosił się do osób, a nie do języka używanego przez nich (zob. McArthur, 1992: 270). Przez nazwę creole zazwyczaj miano na myśli osobę urodzoną $\mathrm{w}$ jednym miejscu, ale zmuszoną do zmiany miejsca zamieszkania, np. niewolnicy, lub potomkowie cudzoziemców osiedlających się na danym terenie, np. potomkowie niewolników afrykańskich lub białych osadników w Indiach (zob. McArthur, 1992: 270).

$\mathrm{Z}$ czasem creole odnosił się także do sposobu życia osób nazywanych $\mathrm{w}$ ten sposób, a dopiero w XIX wieku uznano, że nazwę tę można stosować także do opisywania języka (zob. McArthur, 1992: 270). Zmiana znaczenia słowa creole wniosła wiele do językoznawstwa, ponieważ dzięki niej rozróżniano dalszy rozwój pidgin (zob. McArthur, 1992: 270). Creole, jak już wspomniałam, jest uznawany za kolejny etap ewolucji (zmian) języka, i traktowany jako powstający z połączenia dwóch języków (zob. McArthur, 1992: 270).

Zanim jednak dana odmiana zasłuży na miano creole przechodzi ona przez fazę pidgin (zob. McArthur, 1992: 270). Istotną cechą dla creoles opartych na językach europejskich są elementy gramatyki, takie jak negacja znajdująca się przed czasownikiem oraz szyk wyrazów w zdaniach (zob. McArthur, 1992: 270). Oczywiście istotnym elementem w procesie ewolucji z pidgin do creole jest kreolizacja. Proces kreolizacji, jak pisze McArthur (1992), może wystąpić w dowolnym momencie podczas zmian zachodzących w wykształconym języku (zob. McArthur, 1992: 271). Ponadto, proces ten może zachodzić zarówno stopniowo, jak i gwałtownie. Trudno jest przewidzieć, w którym momencie zachodzących zmian proces ten wystąpi (zob. McArthur, 1992: 271). Jak wspomniałam powyżej, kreolizacja jest procesem, który występuje stopniowo lub nieoczekiwanie. Może on także zajść na skutek zapożyczeń, które wnikają do danego języka (zob. McArthur, 1992: 271).

W językoznawstwie wprowadzono również termin 'dekreolizacja', który to termin określa proces polegający na dominacji creole nad językiem, który stał na pozycji superstratowej (McArthur, 1992: 271). Proces ten zachodzi podczas ponownego kontaktu creole z językiem, który stanowi jego podstawę (np. język angielski w English based creoles) (zob. McArthur, 1992: 271). Poniżej przedstawiam kontinuum prezentujące omówione wcześniej etapy: 


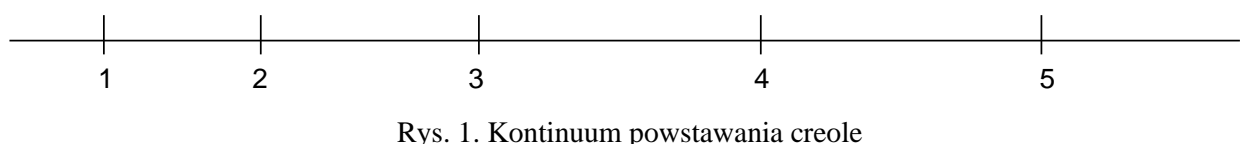

Rys. 1. Kontinuum powstawania creole

1 spotkanie języków; 2 pidgin $; 2$ creole; 4 ponowne spotkanie języków; 5 dekreolizacja

Istotne jest zwrócenie uwagi na fakt, iż zarówno creole, jak i pidgin wywodzą z połączenia dwóch języków, z których jeden znajduje się na pozycji substratowej, a drugi na superstratowej (zob. McArthur, 1992: 270). Substrat (z ang. substrate) jest to język, który podczas kontaktu dwóch języków wpływa na język bardziej dominujący (zob. McArthur, 1992: 999). Z kolei język określany mianem superstrate jest językiem, który podczas kontaktu z innym językiem wpływa na niego z pozycji dominującej (zob. McArthur, 1992: 1005-1006). Innymi słowy, to język superstratowy stanowi podstawę tworzenia się pidgin lub creole, ponieważ jest językiem dominującym, z kolei język substratowy stanowi swojego rodzaju dopełnienie języka superstratowego, uwzględniając oczywiście wszelkie poziomy organizacji języka, takie jak: fonetyka, fonologia, morfologia, leksyka oraz gramatyka. Na przykład w Jamaican Creole językiem substratowym jest język jamajski, z kolei superstratowym - angielski.

Jak już wspomniałam, jednym z dwóch najbardziej interesujących mnie zagadnień jest pidgin, który stanowi etap poprzedzający powstawanie creole. Otóż nazwa pidgin jest używana do określenia języka, który powstaje na skutek kontaktu minimum dwóch języków (zob. McArthur, 1992: 778). Tak więc pidgin powstaje na skutek kontaktu minimum dwóch języków i na przestrzeni lat służył kupcom np. z Afryki do komunikowania się z Europejczykami (zob. McArthur, 1992: 778). Między XVII a XX wiekiem uważano, że pidgin był używany tylko w kontaktach handlowych, jednak obecnie językoznawcy uważają pidgin za język stosowany w komunikacji między dwiema grupami, które posiadają różne języki rodzime (zob. McArthur, 1992: 778). Istotną cechą pidgin jest fakt, iż żaden $\mathrm{z}$ nich nie stanowi języka rodzimego dla żadnej z grup posługujących się nimi (zob. McArthur, 1992: 778). Proces pidginizacji (tj. uproszczenia) zachodzi w określonych warunkach, jednakże może również wystąpić podczas nauki języka nierodzimego, kiedy to osoba nabywająca umiejętności komunikacyjne danego języka nierodzimego opanowuje tylko ich część, a jednocześnie poddaje je nadal, bardziej lub mniej świadomie, działaniom swojego języka ojczystego (zob. McArthur, 1992: 778). Obecnie opinie językoznawców na temat warunków powstawania pidgin są podzielone. Część badaczy uważa, że aby pidgin mógł powstać, potrzebny jest kontakt dwóch dowolnych języków, z kolei istnieje także grupa badaczy, którzy twierdzą, że aby proces pidginizacji mógł nastąpić, konieczny jest kontakt więcej niż dwóch języków (zob. McArthur, 1992: 778). 
Pidgin charakteryzuje się ograniczonym zasobem leksykalnym oraz zredukowaną częścią reguł gramatycznych, przy czym zasoby leksykalne zaczerpnięte są z języka superstratowego, z kolei morfologia z języka substratowego (zob. McArthur, 1992: 779). Gramatyka w pidgin jest bardzo uproszczona (zob. McArthur, 1992: 779), stąd też nazwa procesu pidginizacji - 'uproszczenie'. Gramatyka jest tworzona zgodnie z zasadą: „pomiędzy formą, a znaczeniem powinien istnieć bliski związek” (zob. McArthur, 1992: 779). Co więcej, każdy morfem powinien pojawić się w zdaniu tylko raz (niedopuszczalne jest powtórzenie) i co najważniejsze, każdy morfem powinien mieć tylko jedną formę (zob. McArthur, 1992: 779).

Wiele rodzajów pidgin nie posiada $\mathrm{w}$ ogóle lub istnieje u nich w niewielkim stopniu fleksja, dlatego też znaczenie danego słowa można wyprowadzić tylko na podstawie kontekstu wypowiedzi (zob. McArthur, 1992: 779). Co więcej, w pidgin można dostrzec niewielką liczbę przyimków, których zadaniem jest oznaczenie zagadnień gramatycznych (zob. McArthur, 1992: 779). Komunikatorzy używający pidgin stosują się do zasad obowiązujących w tym języku, co sprawia, że pidgin jest uważany za język o wysokim stopniu regularności (zob. McArthur, 1992: 779).

Ponadto pidgin jest językiem wielofunkcyjnym, co oznacza, że jeden element może pełnić w zdaniu wiele funkcji (zob. McArthur, 1992: 779). Jak wspomniałam, pidgin mają ograniczone słownictwo, ale nie sprawia to, że komunikatorzy mają trudności z komunikacją werbalną. Otóż, jeśli w danym pidgin nie istnieje słowo na opisanie jakiejś rzeczy lub zjawiska, używają oni peryfrazy, czyli opisu lub metafory, aby przekazać swój komunikat (zob. McArthur, 1992: 779).

Zostały wyróżnione cztery etapy pidgin: żargon, trwały pidgin, rozszerzony pidgin oraz creole (zob. McArthur, 1992: 779). Nazwa trwały pidgin, jak pisze McArthur (1992), odnosi się do regularnej, złożonej i ograniczonej normami użycia formy językowej (zob. McArthur, 1992: 780). Z kolei rozszerzony pidgin charakteryzuje się stabilnością i złożonością gramatyczną, a także statusem (zob. McArthur, 1992: 780). Niejednokrotnie rozszerzony pidgin jest uważany za lingua franca i może posiadać status języka oficjalnego (zob. McArthut, 1992: 780). Jeśli chodzi o teorie na temat powstawania pidgin to zostały wyszczególnione trzy. McArthur (1992) przedstawił następujące teorie: uniwersalna, jednorodna i wielorodna (zob. McArthur, 1992: 780).

Teoria uniwersalna zakłada, że niektóre systemu komunikacji pojawiają się naturalnie ze względu na uwarunkowania historyczne i społeczne (zob. McArthur, 1992: 780). Teorie wielorodna zakłada powstanie pidgin w wyniku błędnego nauczania i uczenia się języka superstratowego, przez co jego formy zostają uproszczone, a dzięki nim można mówić o powstaniu pidgin (zob. McArthur, 1992: 780). Jednorodona teoria powstawania pidgin zakłada jednak, że pidgin oparte na językach europejskich mają wspólne źródło pochodzenia (McArthur, 1992: 780). 
Jak już wspomniałam, pierwszym stadium tworzenia pidgin jest żargon. W niniejszym opracowaniu poświęcę mu więcej uwagi. Wstępna definicja żargonu oraz jego odmienność od gwary zostały już w tym artykule przedstawione. Żargon jest zatem charakterystyczną formą językową używaną przez określoną grupę, najczęściej zawodową (McArthur, 1992: 543). Żargon charakteryzuje się nie tylko wyspecjalizowanym słownictwem, ale także specyficzną i charakterystyczną dla każdej z grup składnią (zob. McArthur, 1992: 543). Oba te elementy sprawiają, że ta forma językowa jest niezrozumiała dla osób spoza danej grupy (zob. McArthur, 1992: 543). Istotną cechą żargonu jest także fakt, iż jeśli jest on używany przez daną grupę, to może stanowić dla niej w pełni efektywną odmianę języka (zob. McArthur, 1992: 544). Żargon wyznacza swojego rodzaju wąską grupę społeczną (tzw. klikę) wśród osób posługujących się daną odmianą. Oznacza to, że należą do niej tylko osoby, które są w stanie zrozumieć dany żargon i oczywiście posługiwać się nim (zob. McArthur, 1992: 544). Istnieje jednak ryzyko związane z używaniem żargonu. Przenoszenie słownictwa i składni z żargonu zawodowego do codziennych rozmów sprawia, że nadawane komunikaty są skomplikowane i niejasne dla ich odbiorców nienależących do danej grupy (zob. McArthur, 1992: 544).

Przedstawione powyżej definicje miały na celu przybliżenie problematyki zagadnienia, które poruszam w tym artykule. Język polski stosowany na agorze wirtualnej jest formą stosunkowo młodą, jednakże ze względu na swoją rozszerzającą się obecność i popularność zasługuje na większą uwagę. Poniżej przedstawiam opis oraz wnioski z przeprowadzonego przeze mnie badania.

\subsection{Opis badania}

Przeprowadzone przeze mnie badanie mające na celu zdefiniowanie etapu, na którym znajduje się język polski na agorze wirtualnej, oparte zostało na ankiecie oraz na obserwacji. Ankieta (Załącznik nr 1) była przeprowadzona w szkołach podstawowych i gimnazjalnych na obszarach miejskim i wiejskim. Zawierała ona dwa pytania dotyczące wyjaśnienia przedstawionych emotikonów (Ochotna, 2012; Ochotna, 2015) oraz skrótów językowych, które są najczęściej stosowane na agorze wirtualnej. Uczniowie zostali poproszeni o wzięcie udziału w ankiecie, aby umożliwić przedstawienie stopnia znajomości podanych emotikonów i skrótów. Celem przeprowadzenia ankiety było wskazanie, czy młode pokolenie zna i rozróżnia przedstawiony emotikony i skróty językowe, czy też nie. Realizacja tego celu badawczego umożliwiłaby określenie etapu rozwoju języka polskiego na agorze wirtualnej. W badaniu wzięło udział łącznie 100 uczniów, w tym 51 dziewcząt i 49 chłopców z obszarów miejskich i wiejskich w przedziale wiekowym od 12 do 18 lat. Dane uczestników ankiety prezentują się następująco: 


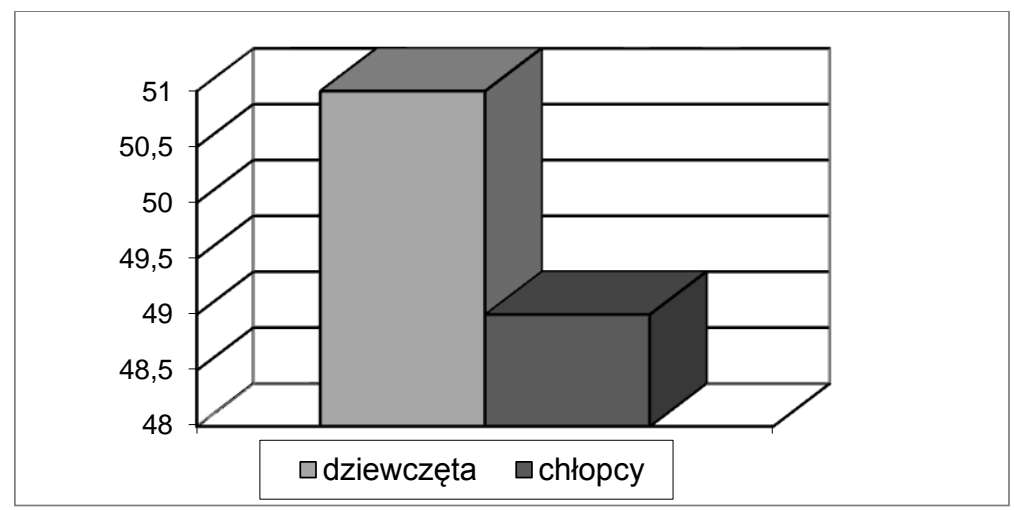

Rys. 2. Liczba dziewcząt i chłopców biorących udział w ankiecie

Natomiast uwzględniając miejsce zamieszkania uczestników ankiety można zauważyć dominację mieszkańców miast w wielkości do 50 tysięcy mieszkańców, co ilustruje poniższy wykres:

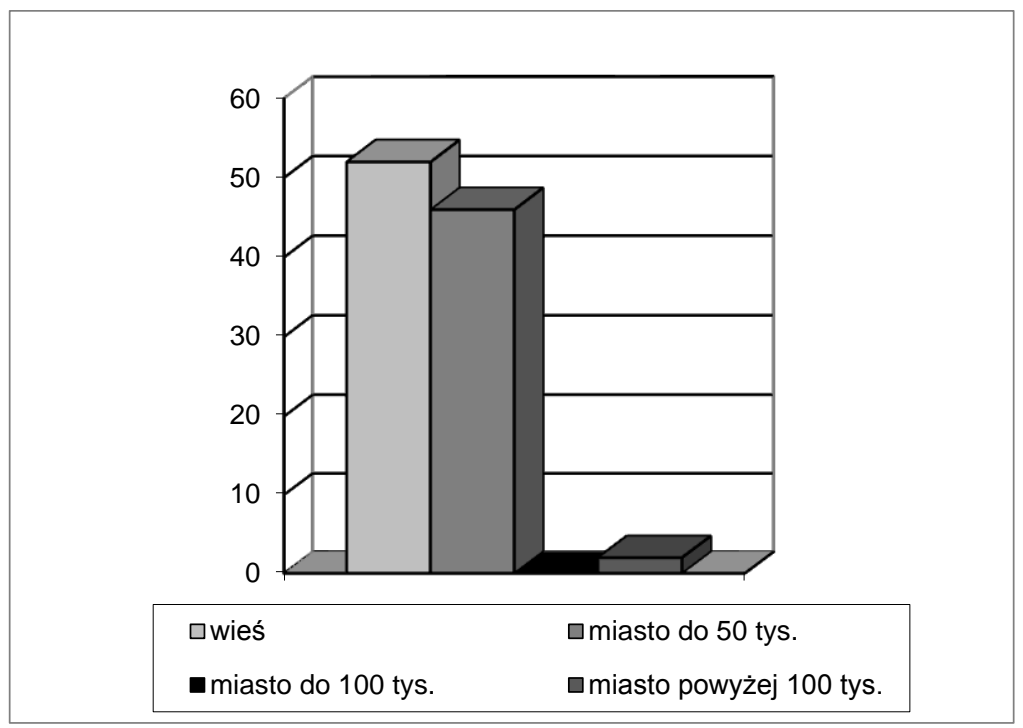

Rys. 3. Proporcja osób z obszarów miejskich i wiejskich biorących udział w ankiecie

Z przeprowadzonej analizy ankiety wynika, iż znajomość emotikonów jest na wysokim poziomie, co przedstawia poniższy wykres: 


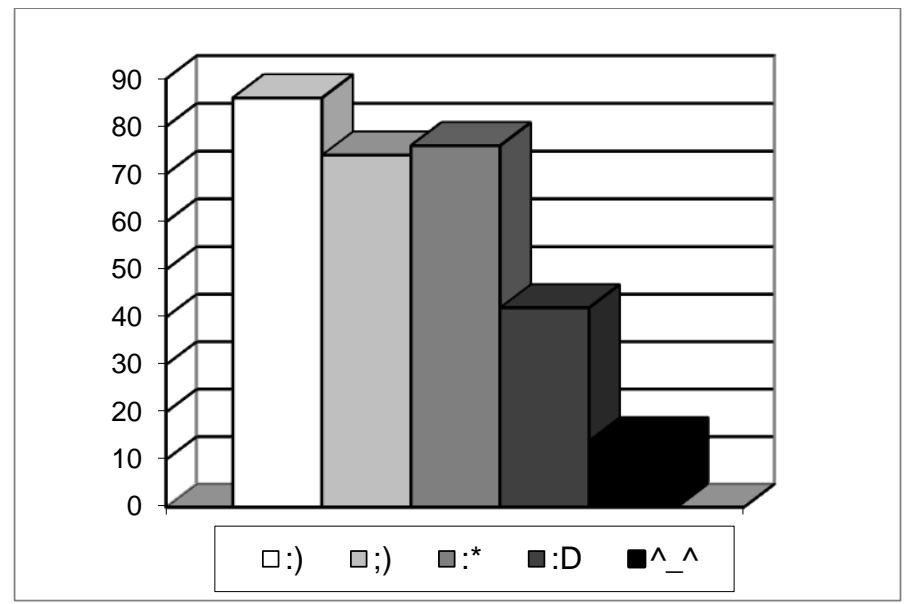

Rys. 4. Znajomość emotikonów

Podobnie można określić znajomość skrótów językowych. Tylko jeden skrót językowy $(L o l)$ jest znany i rozpoznawany przez mniej niż 50\% ankietowanych:

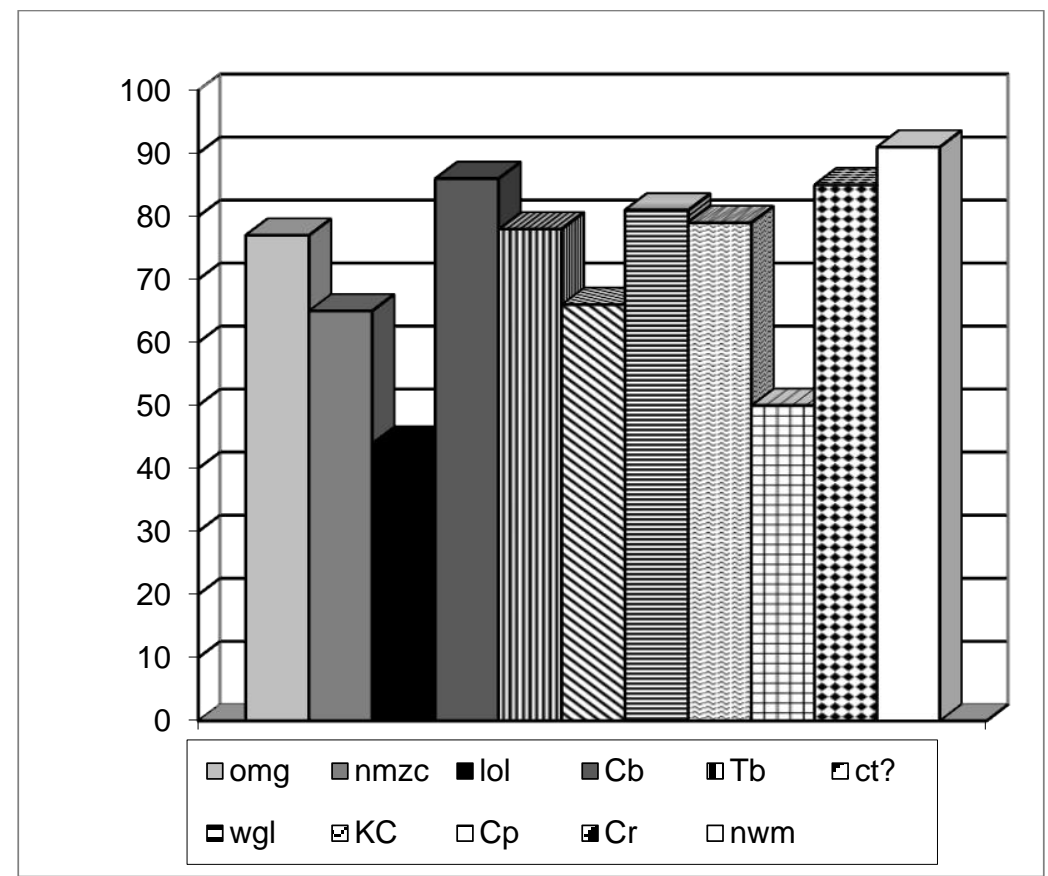

Rys. 5. Znajomość skrótów językowych 


\subsection{Wnioski na podstawie analizy badania i obserwacji}

Teza, którą przyjęłam, jest następująca: „Język polski agory wirtualnej może zostać uznany za żargon”. $\mathrm{Z}$ analizy przeprowadzonego badania oraz z prowadzonych przeze mnie obserwacji młodzieży wynikają następujące wnioski:

1) Ankietowani z obszarów wiejskich znają i potrafią nazwać więcej skrótów językowych przedstawionych $w$ ankiecie.

Różnica w rozpoznawaniu skrótów językowych między ankietowanymi z obszarów wiejskich i miejskich jest niewielka, chociaż zauważalna. Oznacza to, między innymi, iż miejsce zamieszkania nie wpływa zasadniczo na używanie języka na agorze wirtualnej.

2) Znajomość niektórych skrótów językowych, np. Lol (z ang. lots of laughs dużo śmiechu) oraz $C p$ (co porabiasz?) przez ankietowanych z obszarów miejskich i wiejskich jest niewielka i nie zależy od obszaru zamieszkania. Znajomość tych skrótów prezentuje się następująco:

Tabela nr 1. Procentowe zestawienie znajomości wybranych skrótów językowych

\begin{tabular}{|c|c|}
\hline Skrót językowy & Odsetek ankietowanych znających dany skrót \\
\hline LOL & $44 \%$ \\
\hline Cp? & $50 \%$ \\
\hline
\end{tabular}

3) Formy językowe, o które byli pytani respondenci w ankiecie, są zazwyczaj stosowane na agorze wirtualnej. Z obserwacji wynika, iż młodzież w wieku od 12 do 15 lat używa na agorze realnej dwóch form językowych: Lol oraz omg (z ang. Oh my God - o mój Boże). Jednakże z przeprowadzonej ankiety wynika, iż $23 \%$ ankietowanych nie zna znaczenia skrótu omg oraz, że ponad połowa ankietowanych (56\%) nie zna znaczenia skrótu Lol.

Dowodzi to, iż oba te skróty ( $\mathrm{Lol}$ i omg) są na tyle popularne wśród młodzieży, że stosowane są pomimo nieznajomości ich składniowego pochodzenia.

4) Nie wszyscy ankietowani znają znaczenie wszystkich przedstawionych emotikonów (zob. Rys. 4) oraz skrótów językowych (zob. Rys. 5) używanych w komunikacji na agorze wirtualnej, co może świadczyć o tym, iż osoba nienależąca do grupy użytkowników agory wirtualnej, ma trudności ze zrozumieniem języka używanego w komunikacji na tej właśnie agorze.

5) Istotnym jest fakt, iż stosowanie emotikonów dominuje w komunikacji na agorze wirtualnej. Tymczasem podczas komunikacji na agorze realnej emocje nadawcy komunikatu są realizowane przez mimikę, gesty, ton głosu, czy postawę. Poniższe rysunki ilustrują najbardziej wyraziste przykłady złości i radości: 


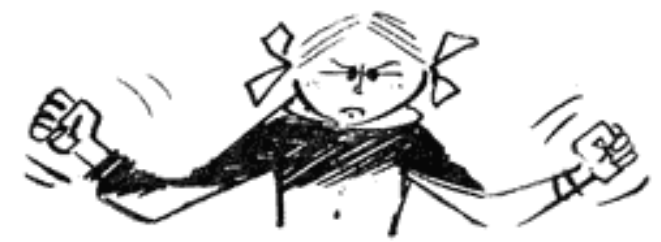

Złość (ŹI 5)

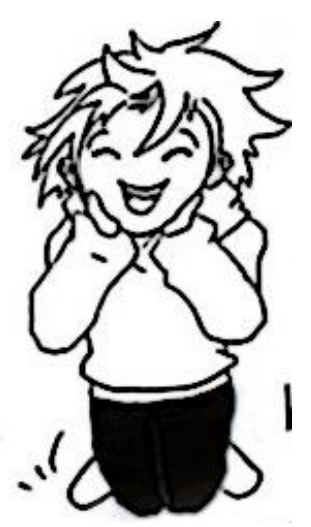

Radość (ŹI 6)

Ponadto emotikony wyrażają emocje istniejące na agorze realnej, są ich reprezentacją rozumianą na całym świecie przez użytkowników agory wirtualnej. Możemy zatem mówić o swoistej uniwersalności emotikonów.

6) Język używany na agorze wirtualnej rozpowszechnia się i jest używany przez coraz młodszych użytkowników tejże agory. Jednak, jak już zostało wspomniane, język ten (poza skrótami językowymi takimi jak Lol i omg) pozostaje w użyciu tylko na agorze wirtualnej i nie jest przenoszony na agorę realną.

7) Bardzo ważnym elementem wskazującym na to, że język polski na agorze wirtualnej jest żargonem, jest fakt, iż nie powstał on z połączenia dwóch języków, co opisano powyżej. Jak już wcześniej wspomniano, pidgin powstaje w wyniku kontaktu co najmniej dwóch języków, aby umożliwić ich użytkownikom komunikację (zob. McArthur, 1992: 779-780). Język polski na agorze wirtualnej jakkolwiek zawiera zapożyczenia (np. Lol, omg), to jednak większość skrótów językowych powstała na skutek utworzenia akronimów (zob. Ochotna, 2012: 81-99).

8) Można dostrzec także przeniesienie form języka polskiego używanych na agorze wirtualnej do komunikacji pisanej na agorze realnej, co widać w przykładach ankiet przytoczonych poniżej: 

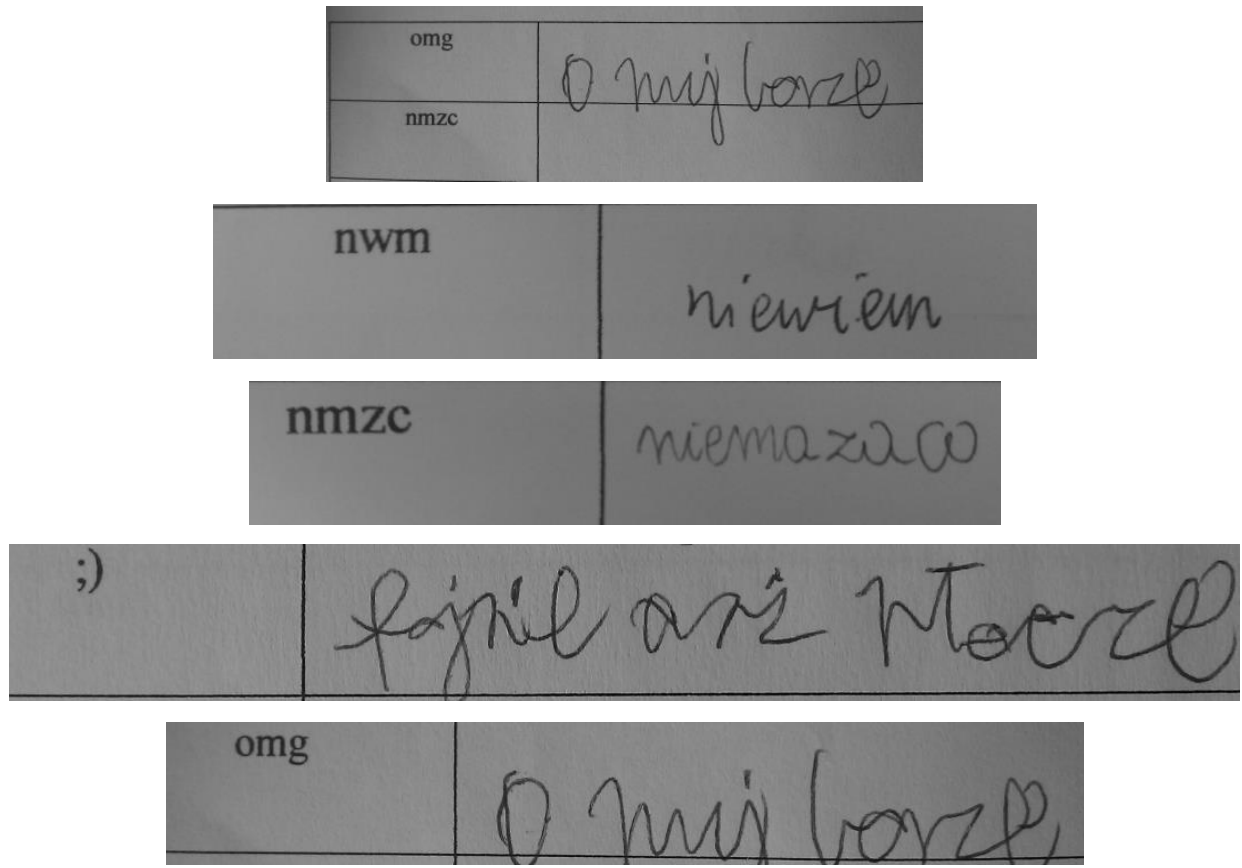

Przeniesienie błędów (w szczególności ortograficznych, interpunkcyjnych oraz brak dużej litery i spacji) do komunikacji na agorze realnej nie zakłóca komunikacji. Pomimo faktu, iż komunikacja na agorze wirtualnej charakteryzuje się uproszczeniem i zminimalizowaniem zdań do zdań prostych i równoważników zdań (zob. Ochotna, 2012: 81-99), nie należy postrzegać języka polskiego na agorze wirtualnej jako pidgin.

\subsection{Podsumowanie}

W niniejszym opracowaniu zajęłam się określeniem etapu, na którym znajduje się język polski stosowany na agorze wirtualnej. Przedstawione zostały definicje takich zagadnień jak: dialekt, żargon, creole oraz pidgin. Ze względu na przedstawione definicje postawiłam pytanie: ,Język polskiej agory wirtualnej - żargon czy pidgin?". Jako tezę przyjęłam, że język polski stosowany na agorze wirtualnej znajduje się na etapie żargonu. Na dowód mojej tezy przedstawiłam wyniki przeprowadzonego badania oraz obserwacji.

Charakterystycznymi cechami żargonu są: żargon jest właściwy dla danej grupy społecznej oraz zawiera właściwe dla niego specyficzne słownictwo. Język polskiej agory wirtualnej spełnia obydwa te kryteria. Jest on charakterystyczny dla grupy 
komunikującej się na agorze wirtualnej z zachowaniem podstaw języka polskiego. Wszelkie zachodzące zmiany w języku używanym na agorze wirtualnej zachodzą w obrębie leksyki. Pozwala to na stwierdzenie, że żargon jest odmianą języka rodzimego (w tym przypadku języka polskiego). Ponadto definicje żargonu stanowią, iż żargon jest językiem charakterystycznym dla danej grupy istniejącej w obrębie danego kraju, np. grupy zawodowej. W tym przypadku grupę tę stanowią użytkownicy agory wirtualnej.

Jak wynika z przeprowadzonego badania, język polskiej agory wirtualnej jest zrozumiały wyłącznie dla użytkowników tej agory. Osoby, które wcześniej nie uczestniczyły w komunikacji na agorze wirtualnej (głównie za pomocą Internetu lub przez SMS-y), mają trudności z rozpoznaniem i nazwaniem zaprezentowanych w ankiecie skrótów i emotikonów. Jak już wspomniałam, język polskiej agory wirtualnej został stworzony tylko w obrębie języka polskiego. Zatem język ten nie powstał na skutek połączenia dwóch lub więcej języków, które to połączenie miałoby pomóc w komunikowaniu się użytkowników agory wirtualnej nienależących do tej samej grupy objętej wspólnym językiem ojczystym.

$\mathrm{Z}$ przedstawionego powyżej podsumowania oraz z przeprowadzonych badań wynika, iż język polskiej agory wirtualnej znajduje się obecnie na etapie żargonu, a nie na etapie pidgin.

\section{Bibliografia}

Bailey, R.W. i J.L. Robinson. (red.) 1973. Varieties of present-day English. New York: MacMillan.

Bright, W. 1992. International encyclopedia of linguistics. Oxford/New York: Oxford University Press.

Crystal, D. 1997. The Cambridge encyclopedia of language. 2nd ed. Cambridge: Cambridge University Press.

Freedman, D.A. i W.S.-Y. Wang. 1995. Language polygenesis. Berkeley: University of California Press.

Graddol, D. 2006. English next. London: British Council.

Hall, R.A. 1973. "Pidgin languages". W zbiorze: Bailey, R.W. i J.L. Robinson. (red.). 91-107.

Kortmann, B. i E.W. Schneider. (red.). 2004. A handbook of varieties of English. 2 Vols. Berlin: Mouton de Gruyter.

McArthur, T. (red.) 1992. The Oxford companion to English language. Oxford: Oxford University Press. 270-272. 289-290. 543-544. 576-577. 606. 778-780. 790-780. 999. 1005-1006.

Ochotna, D. 2012. "Struktura komunikatów SMS-owych: podejście ekolingwistyczne”. W zbiorze: Puppel, S. (red.). 81-99.

Ochotna, D. 2015. Zróżnicowanie form komunikacyjnych na "agorze wirtualnej": analiza komunikacji werbalnej i niewerbalnej w odniesieniu do hybrydowego porzadku komunikacyjnego. Nieopublikowana rozprawa doktorska. Poznań: Wydział Neofilologii UAM.

Mufwene, S.S. 2009. "The evolution of language: hints from Creoles and Pidgins". W zbiorze: Wang, W. S.-Y. i J. Minett. (red.). 1-33.

Puppel, S. (red.). 2007. Ochrona języków naturalnych. Poznań: Katedra Ekokomunikacji UAM.

Puppel, S. (red.). 2012. Transkomunikacja II. Poznań: Katedra Ekokomunikacji UAM. 
Sobol, E. (red.). 1992. Maty stownik języka polskiego PWN. Warszawa: Wydawnictwo Naukowe PWN. 243. 1175.

Wang, W. S.-Y. i J. Minett. (red.). 2009. Language evolution and the brain. Hong Kong: City University of Hong Kong Press.

Wardhaugh, R. 1992. An introduction to sociolinguistics. Oxford: Blackwell.

\section{Źródla internetowe}

ŹI 1 żargon

http://sjp.pwn.pl/szukaj/\%C5\%BCargon

ŹI 2 żargon

http://sjp.pl/\%BFargon

ŹI 3 gwara

http://sjp.pl/gwara

ŹI 4 peryfraza

http://sjp.pwn.pl/szukaj/peryfraza

ŹI 5 złość

http://www.klubkma.pl/archiwum/kma/46_zlosc.shtml

ŹI 6 radość

http://takchcezyc.pl/blog-odkrywcy/kieruj-sie-radoscia/ 
